УДК 811.161.2’276.45

DOI https://doi.org/10.26661/2414-9594-2021-1-21

\title{
ДЕЯКІ ЗАУВАГИ ЩОДО ПРОТООФЕНСЬКОЇ ОСНОВИ УКРАЇНСЬКИХ АРГО
}

\author{
Редько С. О. \\ кандидат філологічних наук, \\ дочент кафедри украӥнознавства \\ Харківський національний університет імені В. Н. Каразіна \\ майдан Свободи, 6, Харків, Украӥна \\ orcid.org/0000-0002-0797-9499 \\ yevhen.redko@karazin.ua,sonsimon@i.ua
}

\author{
Ключові слова: \\ східнослов'янські \\ субстандартні системи, \\ украӥнські лірницько- \\ ремісницькі аріо, сочіолект \\ володимирських офенів, \\ порівняльно-історичне \\ вивчення арто, лексичні \\ паралелі.
}

Статтю присвячено дослідженню зв'язків між українськими арго та соціолектом володимирських офенів у контексті порівняльно-історичного вивчення східнослов'янських субстандартних систем. Основну увагу приділено протоофенській теорії формування східнослов'янських арго, запропонованій російським мовознавцем Василем Бондалетовим, яку критично оцінено з огляду на лінгвальні й екстралінгвальні особливості розглядуваних соціальних діалектів. Сумніву піддано твердження про генетичну первинність офенського соціолекту щодо українських арго й закцентовано на контактному характері взаємодії згаданих субстандартних систем. В основу статті покладено зіставний аналіз одинадцяти українських лірницьких арго, зафіксованих у мовознавчих та етнографічних розвідках упродовж другої половини XIX - початку XXI століття, і найрепрезентативнішого «офенського» джерела-словника соціолекту володимирських мандрівних торговців, що його зібрав у 1850-х роках Володимир Даль. Українсько-офенські арготичні лексичні паралелі проаналізовано за кількісними та якісними параметрами, кількісні показники розглянуто 3 огляду на територіальні особливості відповідних арго. Визначено, що загальна кількість лексичних збігів залежить від обсягу й ареалу поширення аналізованих субстандартних систем і може свідчити лише про конвенційну спорідненість офенського соціолекту з українськими арго. Якісні параметри українсько-офенських зв'язків досліджено на матеріалі фіксованої множини лексем, яка дає змогу помітити численні розбіжності між українською й офенською лексикою на рівні базових понять і найпоширеніших слів. У межах цієї множини окремо досліджено кілька груп офенських арготизмів за частотністю збігів, визначено загальні особливості таких міжарготичних зв'язків. Зауважено, що ймовірна генетична вторинність українських лірницьких соціолектів щодо соціолекту офенів може грунтуватися лише на спільному фонді грецьких запозичень у східнослов'янських арго, однак етимологічні та семантичні особливості грецизмів не дають переконливих свідчень на користь цього припущення. 


\title{
SOME NOTES ON THE PROTOOFENIAN BASIS OF THE UKRAINIAN ARGOTS
}

\author{
Redko Ye. O. \\ Candidate of Philological Sciences, \\ Associate Professor at the Ukrainian Studies Department \\ V. N. Karazin Kharkiv National University \\ Svobody square, 6, Kharkiv, Ukraine \\ orcid.org/0000-0002-0797-9499 \\ yevhen.redko@karazin.ua,sonsimon@i.ua
}

Key words: East Slavic substandard systems, Ukrainian lyrists' and craftsmen' argots, sociolect of Volodymyr ofens, comparative and historical study of argots, lexical parallels.
The article is devoted to studying the relationships between the Ukrainian argots and Volodymyr ofenyas' in the context of the comparative and historical research of East Slavic substandard systems. The main attention is focused on protoofen theory of forming East Slavic argots offered by Russian linguist Vasilii Bondaletov. The theory was criticized because of lingual and extra lingual peculiarities of social dialects. There were some doubts about the genetic origin of ofenyas' sociolect from the Ukrainian argots, also there was emphasized on the contact character of substandard systems interaction. The article is based on the comparative analysis of eleven Ukrainian lyrists' sociolects mentioned in the lingual and ethnographical studies during the second half of the XIX century and in the early XXI one, as well as the most important ofenyas' source - the sociolect dictionary of Volodymyr wandering traders, which was created by Volodymyr Dahl in the 1850s. Lexical parallels between Ukrainian and ofenian argots are analyzed by quantitative and qualitative parameters. Quantitative parameters are considered according to the territorial peculiarities of the argots mentioned above. In particular, we have determined that the total number of lexical coincidences depends on the quantity and geography of spreading the analyzed substandard systems and may show only conventional similarity of ofenyas' sociolect and the Ukrainian one. Qualitative parameters of Ukrainian and ofen relanships are studied on the material of the certain number of lexical units enabling to notice various differences between Ukrainian and ofenian lexis on the level of main notions and the most spread words. Within the certain number of lexical units mentioned above, several groups of ofenyas' argots by coincidence frequency are considered. Besides, general peculiarities of such inter argots relationships are analyzed. We have concluded that probable genetic recurrence of Ukrainian lyrists' sociolects to ofens' ones may be based only on a common fund of Greek borrowings in East Slavic argots. Nevertheless, etymological and semantic peculiarities of these Greek borrowings don't prove such a statement.
У 1987 р. в російському місті Рязань вийшов друком навчальний посібник Василя Бондалетова «Типология и генезис русских арго» [5], у якому автор, опрацювавши матеріал понад 100 східнослов'янських соціолектів, визначив завдання порівняльно-історичного вивчення варіантів арго й дослідив типологію спільних та відмінних рис у них. Проаналізувавши різні групи лексем, Василь Бондалетов дійшов висновку, що всі російські арго безпосередньо чи опосередковано походять 3 «офенської мови»-умовної мовиперших східнослов' янських мандрівних торговців - i немає жодної арготичної мікросистеми, не пов'язаної із цією «мовою» $[5$, c. 41$]$.
Зазначені спостереження Василь Бондалетов спробував застосувати до українських i білоруських соціолектів. Указавши на лексичну подібність згаданих соціолектів до російських арго, він зауважив, що жоден дослідник докладно не зіставив білоруського й українського субстандартного матеріалу 3 російськими соціолектами, а отже, зв'язки між арго східнослов'янських народів досі не 3'ясовані. Намагаючись визначити передусім спільність між українськими і білоруськими арго й офенською мовою, Василь Бондалетов проаналізував відповідні соціолекти і стисло зрезюмував отримані результати. У його присуді йдеться про те, що всі східнослов'янські арго 
беруть початок у спільному лексичному фондi (тут і далі курсив наш $-\epsilon$. Р.), який виник до розпаду східнослов'янської етнічної та мовноі $\epsilon д н о с т і$ (такий фонд названо «протоофенською мовою»); про це свідчать шар офенської лексики в українських i білоруських арго, зіставний 3 «офенізмами» у більшості російських арго, однаковий інвентар офенських лексем і їхне центральне місце в усіх східнослов'янських арготичних мікросистемах [5, с. 46-47].

Протоофенська теорія через брак альтернативних студій $\mathrm{i}$ великий авторитет Василя Бондалетова як провідного російського арголога посіла чільне місце у славістичній соціолектології. Сумніви щодо ii істинності висловила тільки сучасна дослідниця російських умовних мов XIX ст. Марина Прийомишева, яка, зіставляючи окремі східнослов'янські соціолекти, визначала, зокрема, питому частку «офенізмів» у них. Такі спостереження вона залишила щодо кількох українських соціолектів, визнавши їхню близькість і вторинність щодо білоруських арго, а не офенської мови $[15$, с. 318$]$. Аналізуючи протоофенську основу східнослов'янських арго, російська лінгвістка була не менш категорична й заперечила іï, зауваживши, що механізм взаємодії умовних мов і вплив на них офенської мови як соціально детермінованої комунікативної системи генетично не зумовлені, а тому спільна генеза цих систем проблематична [15, с. 230].

Зважаючи на полярність поглядів щодо «протоофенської основи» східнослов'янських apro, недостатню увагу згаданих дослідників до української соціолектної проблематики й незалученість великого масиву українських арго, у пропонованій статті ми спробуємо висловити деякі зауваги щодо ймовірної «протоофенськості» українських історичних соціолектів і подати об’єктивну картину українсько-офенських зв'язків.

У протоофенській теорії найперше впадає у вічі те,щоіїавторприпасовуєгенезусхіднослов'янських соціолектів до теорії спільної давньоруської мови, яка розпалася в XIV-XV ст. (провідна в радянській та російській лінгвістиці, ця теорія неодноразово зазнавала критики й була грунтовно спростована, зокрема, у [14; 18] та інших). Власне Василь Бондалетов намагався пояснити соціолектні явища в річищі традиційного радянського мовознавства, зокрема історії східнослов'янських літературних мов, хоч такий підхід суперечливий, передусім 3 огляду на специфічність аналізованого матеріалу та його почасту незіставність із літературномовними процесами. Вочевидь, дослідник і сам розумів сумнівність свого підходу, зауважуючи, що генетична спільність арго не тотожна генетичній спільності мов і діалектів, адже арто становить особливу лексичну систему, а не загальну мовну структуру [5, с. 50]. I справді, арго - це деяка сукупність лексем, уживаних у закритій соціальній групі (традиційно за їхню основну функцію визнають функцію конспіративну). За таких умов арго закриті від зовнішнього світу, комунікативно обмежені, а їхні носії спілкуються лише зі «своїми». Отже, навряд можна припустити, що різні соціальні групи, наприклад офені й українські лірники чи білоруські прошаки, навіть за спільності мандрівного способу життя та праці, мали спільну мову, адже тоді втрачає сенс соціолектна криптолалічність. За таких історикомовних обставин вірогідно, що окремі лексеми чи групи лексем потрапляли 3 одного арго в інше під час безпосередніх зв' язків їхніх носіїв (як це наочно підтверджують процеси в сучасних жаргонах i сленгу). Ось чому будь-яку кількісно зумовлену спільність чи подібність арго варто визнати за наслідок активних міжсоціолектних контактів. Далі ми спробуємо підтвердити таку позицію, проаналізувавши українсько-офенські арготичні паралелі за кількома параметрами й методами.

\section{1. Кількісні параметри досліджуваного} матеріалу

Найперше, на нашу думку, належить зважити на кількісні параметри офенсько-українських арготичних зв' язків. Майже всі збирачі й дослідники українських арго (див., наприклад, [1, с. 449; 9 , с. $181 ; 16$, с. 22]) зазначають, що ці соціолектні системи мають багато спільних лексем 3 іншими східнослов'янськими арго, однак у наукових розвідках лише зрідка можна віднайти будь-які показники, що оприявнюють таку спільність. I Василь Бондалетов, i Марина Прийомишева подають інформацію щодо лексичних збігів між різними соціолектами саме в контексті зв'язків офенської мови з іншими арго, щоправда, їхні дані досить обмежені й дещо різняться. Попри це, в обох дослідників кількість офенських лексем в українських арго не перевищує 20-25\% (виняток становить арго чернігівських лірників і прошаків, у якому Василь Бондалетов визначає 25-35\% лексики як офенську з походження; див. [5, с. 46]). Зважаючи на очевидну фрагментарність зазначених даних, ми проаналізували кількісні параметри «офенізмів» в українських арго й узагальнили цю інформацію в таблиці. У ній матеріали одинадцяти українських соціолектів, зібраних упродовж кінця XIX - початку XXI ст., зіставлені 3 найрепрезентативнішим офенським джерелом - «Офенско-русским» та «Русско-офенским словарем», які уклав згідно 3 розпорядженням міністра внутрішніх справ Російської імперії графа Перовського в 1850-х рр. Володимир Даль (понад 6000 лексем) [4]. Українські арготичні матеріали в таблиці 1 угруповано за територіальним принципом, зокрема виділені соціолектні мікрогрупи - східноукраїнська, 
Таблиця 1

Українські арготичні матеріали

\begin{tabular}{|c|c|c|}
\hline Соціолект & $\begin{array}{c}\text { Збіги } \\
\text { (варіанти) }\end{array}$ & Тотожні лексеми \\
\hline \multicolumn{3}{|c|}{ Східноукраїнські соціолекти } \\
\hline Харківські невлі (далі - ХН) [10] & $53(27 \%)$ & $16(8 \%)$ \\
\hline Слобожанські лірники (далі - СЛ) [11] & $60(26 \%)$ & $16(7 \%)$ \\
\hline Полтавські лірники (далі - ПЛ) [11] & $68(16 \%)$ & $11(3 \%)$ \\
\hline \multicolumn{3}{|c|}{ Північноукраїнські соціолекти } \\
\hline Чернігівські старці (далі - ЧС) [17] & $53(27 \%)$ & $11(6 \%)$ \\
\hline Чернігівські кобзарі та лірники (далі - ЧК) [12] & $63(31 \%)$ & $11(6 \%)$ \\
\hline \multicolumn{3}{|c|}{ Західноукраїнські соціолекти } \\
\hline Галицькі лірники (далі - ГЛС) [16] & $66(20 \%)$ & $15(5 \%)$ \\
\hline Галицькі лірники (далі - ГЛГ) [7] & $96(18 \%)$ & $23(4 \%)$ \\
\hline Подільські лірники (далі - ПЛ) [11] & $84(18 \%)$ & $18(4 \%)$ \\
\hline \multicolumn{3}{|c|}{ Волинські соціолекти } \\
\hline Волинські лірники (далі - ВЛр) [9] & $136(9 \%)$ & $44(3 \%)$ \\
\hline Волинські старці (далі - ВС) [2] & $78(14 \%)$ & $24(4 \%)$ \\
\hline Волинські лабори (далі - ВЛб) [1] & $40(16 \%)$ & $11(4 \%)$ \\
\hline
\end{tabular}

північноукраїнська, волинська.

Із цієї таблиці зрозуміло, що найбільше збігів і тотожних лексем 3 офенською мовою мають кількісно великі соціолекти. Проте у відсотковому відношенні офенська лексика в кожному 3 них представлена менш ніж на $20 \%$, що навряд варто трактувати як свідчення безпосередньої генетичної спорідненості. Натомість у менших соціолектах «офенізмів» процентно більше - такі соціолекти безпосередньо контактують 3 ареалом російських apго, тож частотність офенських слів у них можна визнати за наслідок міжарготичних впливів. Водночас що далі соціолект побутує від потенційного ареалу офенської лексики, то менший відсоток офенізмів у ньому: у контактних соціолектах цей рівень коливається від 25 до 35\%, у неконтактних - від 10 до 20\%.

Звісно, кількісні збіги не завжди стають релевантним інструментом, щоб встановити спорідненість арго: кількість спільних лексем може бути досить висока, однак у самому соціолекті такі лексеми становитимуть відносно невелику частку (наприклад, арго волинських лірників має найбільше умовних «офенізмів», проте їхня частка в ньому чи не найменша 3-поміж усіх українських арго). Відповідно кількісні параметри логічно поєднати з якісними показниками міжсоціолектної взаємодії, оприявненими в генетико-типологічних особливостях конкретних арготизмів чи їхніх груп.

2. Якісні параметри досліджуваного матеріалу

Щоб встановити такі якісні параметри, потрібна більш-менш чітка методологія, застосовна до проблем мовної та діалектної дивергенції. Традиційні кількісні критерії самі собою не дають змоги розв'язати окреслену проблему, однак якщо їх використовувати щодо обмеженої й перевіреної множини лексем, можна отримати досить виважені й об'єктивні результати. За таку множину в цій статті вибрані дві групи лексем: 1) списки базових понять (за зразок узято списки М. Свадеша та С. Яхонтова, використовувані в лінгвістичній компаративістиці для встановлення спорідненості мов) i 2) 125-слівний список В. Бондалетова [5, с. 9-10], у якому подані арготизми, найчастотніші в російських історичних соціолектах і який став підгрунтям для його протоофенської теорії (до того ж майже всі слова із цього списку наявні в офенських словниках Володимира Даля).

Вибір зазначених лексичних груп зумовлено тим, що ядро арготичної системи формують саме базові лексеми на позначення побутових реалій та явищ. Якщо припустити, що «протоофенське арго» стало основою для всіх східнослов'янських соціолектів, то в ycix цих мікросистемах має бути відбита передусім така базова лексика; водночас відсоток базових лексем у кожному арго має бути досить високий: традиційно помітну спорідненість репрезентують 75-85\% спільних лексем, тоді як конвенційну - лише 15-30\%. Звісно, у дослідженні соціолектів не завжди коректно використовувати принципи й методи, застосовні до історії літературних чи національних мов, однак i список М. Свадеша, і список С. Яхонтова добре зарекомендували себе саме як фіксована множина лексем, що дає досить об'єктивні результати (обидва списки скорочені, адже не всі базові поняття наявні в соціолектах; зокрема, вилучені поняття «сухий», «круглий», «попіл», «хмара», «пливти» та інші). 
Результати таблиці 2 корелюють із загальними кількісними показниками i вказують на те, що великі соціолекти мають більше базових офенських слів, ніж невеликі арго. Подані списки свідчать, що в українських арго на рівні базової лексики загалом від 20 до 35\% слів спільні 3 «офенською мовою»; прикметним $\epsilon$ досить високий рівень базової лексики в арго полтавських лірників, який можна пояснити полігенезним походженням цього соціолекту: з одного боку, він дуже близький до слобожанських арго, із другого, зазнав впливу як північноукраїнських, а отже, і білоруських, такізахідноукраїнських соціолектів. Важливо наголосити, що кількість слів у стійкішій частині базової лексики не набагато, але майже всюди більша за кількість слів із менш стійкої частини. Якби пропорція була помітно більша, можна було б дійти висновку про генетичну спорідненість зіставлюваних систем, однак маємо баланс, а він може свідчити як про спорідненість лексем, так i про їхню запозиченість. Тобто списки базових понять переконливо не доводять близької спорідненості порівнюваних арго (а вона мала б бути очевидна й виразно оприявнена, адже йдеться про нетривалий часовий період, у якому функціонували ці соціолекти, і про їхню структурну консервативність - змінюваність у закритих лексичних системах 3 усталеними соціумними традиціями досить низька).

Натомість, зіставивши офенізми зі списку В. Бондалетова з матеріалами українських арго, ми отримали набагато цікавіші результати (табл. 3).

Якщо уважно подивитися на список В. Бондалетова, то можна помітити, що майже половини арготизмів із нього немає в жодному українському арго. Замість них часто вживано лексеми, наявні в усіх чи більшості українських соціолектів (водночас таких лексем немає в офенській мові): бусать («пити») - керити $[16$, с. 32], кирити $[2$, с. $271 ; 6$, с. 706; 9, с. 191; 11 , с. 411$]$, кірити $[1$, с. $457 ; 2$, с. 271 ; 9, с. 191 ; 10 , с. $156 ; 17$, с. 88], перить [12, с. 90]; вериать («дивитися») - влспати [11, с. 389], вліпати $[2$, с. $269 ; 6$, с. $704 ; 7$, с. 10], ліпати [1, с. 457; 16, с. 36], сліпати [11, с. 396], улепать [17, с. 89],
Таблиця 2

Дослідження соціолектів

\begin{tabular}{|c|c|c|}
\hline Соціолект & $\begin{array}{c}\text { Список } \\
\text { М. Свадеша } \\
\text { (82 слова) } \\
\end{array}$ & \begin{tabular}{|c|} 
Список \\
С. Яхонтова \\
(33 слова)
\end{tabular} \\
\hline \multicolumn{3}{|c|}{ Східноукраїнські соціолекти } \\
\hline Харківські невлі [10] & $13(16 \%)$ & $8(24 \%)$ \\
\hline $\begin{array}{c}\text { Слобожанські лірники } \\
\text { [11] }\end{array}$ & $16(20 \%)$ & $10(29 \%)$ \\
\hline Полтавські лірники [11] & $23(28 \%)$ & $15(44 \%)$ \\
\hline \multicolumn{3}{|c|}{ Північноукраїнські соціолекти } \\
\hline Чернігівські старці [17] & $13(16 \%)$ & $10(29 \%)$ \\
\hline $\begin{array}{c}\text { Чернігівські кобзарі та } \\
\text { лірники [12] }\end{array}$ & $17(21 \%)$ & $10(29 \%)$ \\
\hline \multicolumn{3}{|c|}{ Західноукраїнські соціолекти } \\
\hline Галицькі лірники [16] & $18(22 \%)$ & $8(24 \%)$ \\
\hline Галицькі лірники [7] & $26(32 \%)$ & $14(41 \%)$ \\
\hline Подільські лірники [11] & $24(29 \%)$ & $11(32 \%)$ \\
\hline \multicolumn{3}{|c|}{ Волинські соціолекти } \\
\hline Волинські лірники [9] & $29(35 \%)$ & $11(32 \%)$ \\
\hline Волинські старці [2] & $20(24 \%)$ & $11(32 \%)$ \\
\hline Волинські лабори [1] & $11(13 \%)$ & $5(15 \%)$ \\
\hline
\end{tabular}

уліпати [9, с. $211 ; 10$, с. 156$]$, хоч в офенській мові $\epsilon$ улеп «око» паралельно із частотнішими вербух, вершало, вершалка «око»; волоха («сорочка») манатка [2, с. 272 ; 6, с. 706; 7, с. 17; 9, с. 197; 10 , с. $156 ; 11$, с. $419 ; 16$, с. $37 ; 17$, с. 88], монатка [12, с. 90]; дряба («вода») - дайка [2, с. 269; 9 , с. 186], деика $[2$, с. $269 ; 16$, с. 30], делька [1, с. 456; 2 , с. $269 ; 6$, с. $704 ; 7$, с. $11 ; 10$, с. $156 ; 11$, с. 392$]$, дельга [2, с. $269 ; 11$, с. $392 ; 12$, с. $87 ; 17$, с. 87]; жулик («ніж») -махир [17, с. 87], махлич [2, с. 273; 6, с. 706; 17, с. 88], махличник [2, с. 273], махлій [9, с. $197 ; 10$, с. 156], махлун, махлюнець, мохлун [9, с. 197], махльовник, мохльовник [2, с. 273; 9, с. 197], махор [12, с. 89], мехир [7, с. 13], нехер $[16$, с. 38]; касей («священник») - каухвир $[12$, с. 90$]$, корх $[1$, с. $457 ; 2$, с. $271 ; 6$, с. 705; 7 , с. $17 ; 9$, с. $193 ; 10$, с. $155 ; 11$, с. $412 ; 16$, с. 33$]$, корхвет [11, с. 412], але кисяев [10, с. 155]; ласый («малий») - мекрий [2, с. 273; 6, с. 706; 7, с. 17; 9, с. 197], мехри [2, с. 273], микри [1, с. 458], мікрий $[10$, с. $156 ; 11$, с. $405 ; 12$, с. $89 ; 16$, с. 37$]$; лухта

Таблиця 3

Зіставлення офенізмів зі списку В. Бондалетова з матеріалами українських арго

\begin{tabular}{|c|c|c|c|c|c|c|c|c|c|c|c|}
\hline Соціолект & ХН & СЛ & ПЛ & ЧС & ЧК & ГЛС & ГЛГ & ПЛ & ВЛр & ВС & ВЛб \\
\hline Збіги & 29 & 36 & 27 & 27 & 25 & 30 & 30 & 34 & 33 & 30 & 19 \\
\hline$\%$ & 23 & 29 & 22 & 22 & 20 & 24 & 24 & 27 & 26 & 24 & 15 \\
\hline
\end{tabular}

\begin{tabular}{|c|c|c|}
\hline Немає арготизмів зі списку В. Бондалетова & 55 & $44 \%$ \\
\hline Наявні в одному українському соціолекті & 10 & $8 \%$ \\
\hline Наявні у 2-4 українських соціолектах & 22 & $18 \%$ \\
\hline Наявні в понад 4 соціолектах, але не в усіх & 30 & $24 \%$ \\
\hline Наявні в усіх українських соціолектах & 8 & $6 \%$ \\
\hline
\end{tabular}


(«каша») - лакша [9, с. 196], лекша [2, с. 272; 6$, с. $706 ; 16$, с. 36$]$, лекше $[17$, с. 90$]$, ликша $[7$, с. 13 ; 11 , с. 401], але лухта [10, с. 155]; мастырить («працювати») - клавити [1, с. 457], клевити [7, с. $17 ; 9$, с. $192 ; 11$, с. $407 ; 16$, с. 33], клевляти [2, с. 271], клевотити [6, с. 705], кревляти [10, с. 156], склавати, склавотати [17, с. 89]; сафить («різати») - макувати [16, с. 36], махлати [9, с. 197], махличати [2, с. 273], махличити [6, с. 706; 11, с. 415], махловати [9, с. 197], махлювати [11, с. 411], михличити [6, с. 706]; трафилка («копійка»)-батійка [1, с. 456;2, с. 268], батуга $[12$, с. $88 ; 17$, с. 87$]$, батузка $[10$, с. 155 ; 11, с. 402]; трубёха («корова») - авлида [6, с. 704], гавлита [16, с. 29], гавлидка [7, с. 10; 11, с. 403], гавритка [2, с. 269; 9, с. 185], євлюдка [17, с. 87], євлютка [12, с. 88], явлидка [11, с. 403], яглитка [2, с. 270]; ухлить («слухати», «чути») слихтати [2, с. 274; 9, с. 207], слихтити [6, с. 707; 7, с. $15 ; 9$, с. 207], слухомити [16, с. 42], слухтати [9, с. 207], але вухляти [11, с. 418], крім того, в українських арго досить багато похідних номенів від слихтити, слухомити.

До цього переліку належать числівники зі списку В. Бондалетова, яких немає в українських соціолектах (крім пенда, однак щодо нього не зрозуміло, ідеться про запозичення з офенського арго чи про різноваріантне адаптування грецизму в різних соціолектах). Така особливість дивує й поготів, адже лексеми на позначення лічби або рахунку, використовувані у грошових операціях, мали б бути однакові за умови генетичної спорідненості арго.

Прикметно, що ізоглоси згаданих лексем охоплюють територію поширення українських та більшості білоруських арго (часто крім могильовських) і лише інколи можуть стосуватися російськотеренних умовних мов (поширених на території сучасних Смоленщини, Брянщини тощо). Вказана особливість наявна й у низки інших базових понять, щодо яких помітні розбіжності між українськими й офенським арго: вячо, скель, скельно, хлябо («багато») - поксо [2, с. 273], посо $[1$, с. $458 ; 6$, с. $706 ; 9$, с. 203 ; 10 , с. $156 ; 11$, с. $389 ; 17$, с. 88$]$; щоправда, у деяких українських соціолектах зафіксовано лексему гальмо, гальомо («багато»), так само наявну в офенських арго; гранатки, греняты, евренёнок, егренёнок («яйцо/яйця») - кито [7, с. 12; 11, с. 426], кima [16, с. 32], кimo [1, с. 457; 2, с. 271; 6, с. 705; 9, с. 192], але євро [17, с. 87], яврята [10, с. 156]; качава, котева, кочева («голова») - гвамозда $[12$, с. 87], главда [2, с. $269 ; 7$, с. $10 ; 9$, с. 185 ; 11 , с. 393], глада [16, с. 29], гловда [9, с. 185], лавда [6, с. 706], але качава [11, с. 394]; луньга, лыньга, люха, сунега («собака») - скел [15, с. 41], скил [7, с. 15; 12, с. 91], скилун [9, с. 206], скиль
[2, с. $274 ; 11$, с. $411 ; 17$, с. 89], скииьь [6, с. 707], скіл [1, с. 458], шкіль [10, с. $155 ; 11$, с. 411]; седмать, седмить («сидеть») - качати [9, с. 190; 12, с. 91], качити $[1$, с. $457 ; 2$, с. $271 ; 6$, с. $705 ; 7$, с. 17 ; 9 , c. $190 ; 16$, c. 32].

Усі зазначені поняття важливі для арготичного середовища, тож досить дивно, чому їх - якщо визнати за аксіоматичну позицію Василя Бондалетова щодо протоофенської основи східнослов'янських арго - витіснили умовні інновації, причому витіснили повсюдно, у всіх соціолектах. Ще важливіше додати, що згадані «інновації» виникали не внаслідок словотвірних процесів, що було б логічно для вторинного номінування, а передусім унаслідок запозичення та трансформації грецьких коренів (зікро («око»), кіто («яйце»), манатка («сорочка»), мікрий («малий»), посо («багато») та інші).

Схожа ситуація $з$ офенізмами, зафіксованими в кількох українських арго. Найчастіше такі лексеми наявні в меншій кількості соціолектів, ніж їхні українські відповідники: наприклад, котюр («хлопець», «поводир») - котер [10, с. 153], котір [11, с. 411], але лабзюк [12, с. 89], лобез [17, с. 88], лобзай [9, с. 196], лобзюк [7, с. 13], лобуз [2, с. 272], хлобняк [11, с. 422]; сумак («хліб»)-сумак [12, с. 91; 17 , с. 89], сумер [2, с. 275], сумера [9, с. 208], але кумса $[1$, с. $457 ; 7$, с. $17 ; 9$, с. $195 ; 11$, с. 422 ; 16, с. 35], кунсо [6, с. 705]; хлить («іти») - хиляти $[11$, с. 423], хлити [2, с. 276], хліти [12, с. 90], хліяти [10, с. 156], але ханджати [2, с. 276], ханджовати $[9$, с. 211$]$, ханджувати $[2$, с. $276 ; 6$, с. 707 ; 11, с. 423], ханжувати [10, с. 156], ханити [17, с. 89]. Водночас чверть лексем зі списку В. Бондалетова становлять арготизми, переважно зафіксовані в українських соціолектах, територіально близьких до російських арго, тобто такі слова відбивають безпосередні контакти 3 російськими арго, генетично пов'язаними 3 «офенською мовою», або із самою «офенською мовою» (ідеться про умовні арготичні «росіянізми» у східноукраїнських i північноукраїнських соціолектах, які могли проникати через ці соціолекти в інші українські арго): антивосы, антихосы («млинці») - ахтимуси [17, с. 87]; бряить, брять («їсти») - бреіти $[12$, с. 88$]$; взю, взюга, здю, здюга, зю («два»), здюгой, зюсный («другий») - зютний («другий») [11, с. 397], зютно («два») [11, с. 426], ютнь («два») [11, с. 426]; громак, громатуха, громать («віз») - грамозка [12, с. 88]; лестюга («капуста») - шелестючка [11, с. 401]; ловак («кінь»)-лавак [12, с. 88]; люсый («милий») -люсий («хороший» $[10$, с. 156$]$, «спритний» [11, с. 419]); мамура «сокира»-маймура [7, с. 13]; чунаться («молитися») - куняться [11, с. 407]. Досить багато таких офенізмів (акруша («хліб»), бакрих («два»), бурдаси («штани»), катруха («шапка»), плеха 
(«лазня»), сковдин («один»), стромух («три»), mpona («борода»)) у соціолекті новоропських шаповалів [13], але генеза цього арго до кінця не 3'ясована.

Майже третину списку В. Бондалетова становлять лексеми зі списку базових понять, наявні в багатьох або всіх українських соціолектах. Переважно такі арготизми запозичені із грецької мови (напр., гальмо - «молоко», ёный - «один», кимать - «спати», кресо-«м'ясо», псала- «риба»,

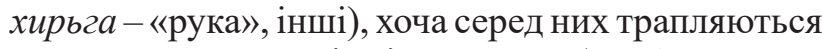
лексеми, запозичені 3 інших мов (стод - «Бог», хаз - «хата»); саме цю лексичну групу Василь Бондалетов використав як основний аргумент на користь арготичної протомови (див. [5]). Проте iз зазначеними лексемами не все так однозначно. Не заперечуючи їхньої репрезентованості у східнослов'янських соціолектах як генетично пов'язаних одиниць, маємо закцентувати на тому, що, імовірно, напрями їхнього запозичення були різні. На це вказує фонетична, морфемна та семантична структура згаданих одиниць. Зокрема, в аналізованій групі є низка лексем, ближчих до етимона, ніж їхній офенський відповідник: гр. $\mu \dot{\varepsilon} \lambda l$ («мед») - пор.: міляс [7, с. 13], миляс [6, с. 705], муляс [9, с. $199 ; 15$, с. 38], омеляс $[11$, с. 406] та оф. амельяс, емеля; гр. Врохиं («дощ») - пор.: paxma [7, с. 14], рахтіü [2, с. 274; 6, с. 707; 7, с. $17 ; 11$, с. $397 ; 16$, с. 40] та оф. аграфон, графон, графыга, грахом, грахон; гр. Эєо́ («Бог») - пор.: охвес [7, с. 14], охвест [11, с. 390], охвис [17, с. 88], фез $[16$, с. 43], фес [2, с. 275], хвес [6, с. 707], хвест [9, с. 211] зі значенням «Бог» та оф. афест

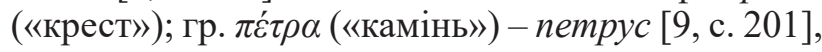
nimpoc $[17$, с. 39], nimpyc [7, с. 14] та оф. кетрус, інші. Цих лексем досить багато, хоча належить визнати, що основу аналізованої групи становлять лексеми, однаково зреалізовані в офенському й українських арго. Отже, встановити, який соціолект був посередником у запозиченні чи ймовірною протоосновою, не видається можливим. Є кілька версій щодо шляхів, якими грецькі лексеми потрапляли у східнослов'янські арго (див.: [3, с. 77-78; 8, с. 408-409; 17, с. 131]), однак жодну версію не можна визнати за геть переконливу. Вочевидь, варто пристати на позицію, що всі можливі джерела запозичення (торгові зв'язки, паломництво, освітні практики, грецькі колонії на території Російської імперіï) різною мірою вплинули на формування спільного фонду грецизмів у східнослов'янських історичних соціолектах. У такому разі ідея будьякої арготичної протооснови скидається на штучний конструкт, адже насправді йдеться про відносно автономні соціолектні континууми, які в різний спосіб взаємодіяли один 3 одним. Це стверджує й Василь Бондалетов, який припускає можливе одночасне виникнення найдавніших східнослов' янських арго [3, с. 78]; такі найдавніші варіанти, з огляду на мандрівний спосіб життя їхніх носіїв, досить легко могли контактувати безпосередньо або - частіше - через територіально контактні арго, у яких відбувалась інтерференція різносоціолектних впливів (на це вказують численні спільні ізолекси у згаданих перехідних арго).

Отже, наявні арготичні матеріали не містять переконливих свідчень на користь генетичної спорідненості між офенською мовою й українськими арго. Радше йдеться про різноспрямовані контакти між окремими східнослов'янськими арго, що зумовили як численні лексичні збіги в таких соціолектних системах, так і одиничні вкраплення в окремих межових арго. У цьому контексті проблема генези східнослов'янських соціолектів потребує дальшого дослідження й осмислення із залученням ширшого матеріалу (передусім білоруських умовних мов) i різноманітніших методів як етимологічного, так і соціолінгвістичного аналізу.

\section{ЛІТЕРАТУРА}

1. Аркушин Г. Арго лаборів. Slavia Orientalis. 2002. T. XLI. № 3. С. 447-471.

2. Аркушин Г. Словник арготизмів мови сліпців-жебраків Західного Полісся. Slavia Orientalis. 1996. T. XIV. № 2. C. 267-277.

3. Бондалетов В. Греческие заимствования в русских, украинских, белорусских и польских арго. (К проблеме генезиса и контактирования социальных диалектов славянских языков). Этимология. 1980. 1982. C. 64-78.

4. Бондалетов В. В.И. Даль и тайные языки в России. Москва : Флинта, 2004. 456 с.

5. Бондалетов В. Типология и генезис русских арго. Рязань, 1987. 84 с.

6. Боржковский В. Лирники. Киевская старина. 1889. Т. XXVI. № 9. С. 653-708.

7. Гнатюк В. Лірники. Лірницькі пісні, молитви, слова, звістки і т. п. про лірників повіту Бучацького. Етнографічний збірник. 1896. Вип. 2. С. 1-76.

8. Горбач О. Арго в Україні. Львів, 2006. 688 с.

9. Дзендзелівський Й. Арго волинських лірників. Studia z filologii polskiej i stowiańskiej. 1979. T. XVI. C. 179-216.

10. Иванов В. Невли. Статистический листок. 1883. № 10. С. 153-156. 
11. Кушпет В. Старцівство: мандрівні старці-музиканти в Україні (XIX - початок XX ст.). Київ, 2007. $592 \mathrm{c}$.

12. Малинка А. Кобзари и лирники. Терентий Пархоменко, Никифор Дудка и Алексей Побегайло. Земский сборник Черниговской губернии. 1903. Вып. 4. С. 60-92.

13. Николайчик Ф. Отголосок лирницкого языка. Киевская старина. 1890. Т. ХХІХ. № 4. С. 121-130.

14. Півторак Г. Походження українців, росіян, білорусів та їхніх мов: міфи і правда про трьох братів слов'янських зі «спільної колиски». Київ, 2001. 148 с.

15. Приемышева М. Н. Тайные и условные языки в России ХІХ в. : в 2-х ч. Санкт-Петербург, 2009.

16. Студинський К. Лірники. Львів, 1894. 56 с.

17. Тиханов П. Черниговские старцы (Псалки и криптоглассон). Труды Черниговской губернской архивной комиссии. Вып. 2. С. 65-158.

18. Shevelov G. A Historical Phonology of the Ukrainian Language. Heidelberg, 1979. 809 p.

\section{REFERENCES}

1. Arkushyn, H. (2002). Argo laboriv [Argot of the churchwardens]. Slavia orientalis. Vol. 51(3). P. 447-471.

2. Arkushyn, H. (1996). Slovnyk argotyzmiv movy sliptsiv-zhebrakiv Zakhidnoho Polissia [Dictionary of West Polissia argot of the blind beggars]. Slavia orientalis. Vol. 14 (2). P. 267-277.

3. Bondaletov, V.D. (1982). Grecheskiye zaimstvovaniya v russkikh, ukrainskikh, belorusskikh i polskikh argo (K probleme genezisa i kontaktirovaniya sotsialnykh dialektov slavyanskikh yazykov) [Greek loanwords in Russian, Ukrainian, Bielorussian and Polish argots (to the problem of the genesis and contacting of Slavic social dialects]. Etymology 1980. P. 64-78.

4. Bondaletov, V.D. (2004). V.I. Dal i taynyye yazyki v Rossii [V. Dal and Russian secret languages]. Moscow: Flinta. 456 p.

5. Bondaletov, V.D. (1987). Tipologiya i genezis russkich argo [Typology and genesis of Russian argots]. Ryazan. 84 p.

6. Borzhkovskyi, V. (1889). Lirnyky [Lyrists]. Kievan Past. Vol. 26 (9). P. 653-708.

7. Hnatiuk, V. (1896). Lirnyky. Lirnytski pisni, molytvy, slova, zvistky i t.p. pro lirnykiv povitu Buchatskoho [Lyrists. Lyrists` songs, prayer, words, news etc in the Buchach county]. The Ethnographic Collection. Vol. 2. P. 1-76.

8. Horbach, O. (2006). Argo v Ukraini [Argot in Ukraine]. Lviv. 688 p.

9. Dzendzelivskyi, Y.O. (1979). Argo volynskykh lirnykiv [Argot of Volyn lyrists]. Studia z filologii polskiej i stowiańskiej. Vol. 16. P. 179-216.

10. Ivanov, V.V. (1883). Nevli [Blind men]. The Statistical Paper. Issue 10. P. 153-156.

11. Kushpet, V. (2007). Startsivstvo: mandrivni spivtsi-muzykantyv Ukraini (XIX-pochatokXX st.) [Beggary: wandering blind musicians (in the nineteenth and early twentieth centuries)]. Kyiv: Tempora. 592 p.

12. Malinka, A. (1903). Kobzari i lirniki: Terentii Parkhomenko, Nikifor Dudka, Aleksei Pobehailo [Kobzars and lyrists: Terentii Parkhomenko, Nikifor Dudka, Aleksei Pobehailo]. The Zemstvo Collection of the Chernihiv Province. Vol. 4. P. 60-92.

13. Nikolaychik, F. (1890). Otgolosok lirnitskogo yazyka [Echo of the lyrists` language]. Kievan Past. Vol. 29(4). P. 121-130.

14. Pivtorak, H.P. (2001). Pokhodzhennia ukraintsiv, rosiian, bilorusiv ta yikhnikh mov: mify i pravda pro trokh brativ slovianskykh zi "spilnoi kolysky" [Origin of Ukrainians, Russians, Byelorussians and their languages. Myths and truth about three Slavic brothers from "common cradle"]. Kyiv: Academia. 148 p.

15. Priyemysheva, M.N. (2009). Taynyye $i$ uslovnyye yazyki v Rossii XIX v. [Russian secret languages and argots in the nineteenth century]. (Vols. 1-2). Sankt-Peterburg.

16. Studynskyi, K. (1894). Lirnyky [Lyrists]. Lviv. 56 p.

17. Tikhanov, P. (1899). Chernigovskie startsy (Psalki i kriptoglasson) [Beggars from Chernihiv. "Psalki i kriptoglasson"]. Writings of the Archive Commission of Chernihiv Province. Vol. 2. P. 65-158.

18. Shevelov, G.Y. (1979). A Historical Phonology of the Ukrainian Language. Heidelberg. 809 p. 